\title{
Methylene blue 1\% solution on the prevention of intraperitoneal adhesion formation in a dog model
}

\author{
Solução de azul de metileno a $1 \%$ na prevenção da formação de aderências \\ intraperitoneais em um modelo experimental em cães
}

\author{
Marco Augusto Machado Silva ${ }^{I}$ Olízio Claudino da Silva ${ }^{I I}$ Luiz Antônio Franco da Silva ${ }^{\text {II }}$ \\ Raquel Cunha Ribeiro ${ }^{\mathrm{II}}$ Paula Marina Brito Jorge ${ }^{\mathrm{IV}}$ Jalily Bady Helou ${ }^{\mathrm{II}}$ \\ Pedro Paulo Maia Teixeirav ${ }^{\mathrm{V}}$ Maurício Veloso Brun ${ }^{\mathrm{VI}}$
}

\begin{abstract}
Intraperitoneal adhesions usually are formed after abdominal surgeries and may cause technical difficulties during surgical intervention, chronic abdominal pain and severe obstructions of the gastrointestinal tract. The current study aimed to evaluate the efficacy of methylene blue (MB) $1 \%$ solution on the prevention of intraperitoneal postsurgical adhesion formation in a canine surgical trauma model. Twenty bitches were submitted to falciform ligament resection, omentectomy, ovariohysterectomy and scarification of a colonic segment. Prior to abdominal closure, 10 bitches received $1 \mathrm{mg} \mathrm{kg}^{-1} \mathrm{MB}$ intraperitoneally (MB group) and 10 bitches received no treatment (control group, CT). On the $15^{\text {th }}$ postoperative day the bitches were submitted to laparoscopy to assess adhesions. The mean adhesion scores were $13.9( \pm 5.6)$ for MB group and $20.5( \pm 6.4)$ for the CT group $(P=0,043)$. In conclusion, the $1 \% \mathrm{MB}$ solution was efficient on the prevention of intraperitoneal postoperative adhesion formation in bitches, especially those involving the colonic serosa.
\end{abstract}

Key words: adhesions, prophylaxis, methylene blue, laparoscopic assessment, surgical trauma, bitches.

\section{RESUMO}

Aderências intraperitoneais se formam frequentemente após cirurgias abdominais, podendo causar dificuldades técnicas durante intervenções cirúrgicas, dor abdominal crônica e obstrução grave do trato gastrintestinal. O objetivo do presente estudo foi avaliar a eficácia da solução de azul de metileno (MB) a 1\% na prevenção da formação de aderências intraperitoneais em um modelo experimental de trauma cirúrgico abdominal em caninos. Vinte cadelas foram submetidas à ressecção do ligamento falciforme, omentectomia, ovário-histerectomia e escarificação da serosa de um segmento de cólon. Antes da síntese abdominal, 10 cadelas receberam $1 \mathrm{mg}$ $\mathrm{kg}^{-1}$ de $\mathrm{MB}$ a $1 \%$ via intraperitoneal (grupo MB) e 10 cadelas não receberam tratamento (grupo controle, CT). No 15 dia pósoperatório, as cadelas foram submetidas à laparoscopia para avaliação da formação de aderências. Os escores de formação de aderências foram 13,8 ( $\pm 5,6)$ para o grupo MB e 20,5 $( \pm 6,4)$ para o grupo CT $(P=0,043)$. A solução de azul de metileno a $1 \%$ foi eficaz na prevenção da formação de aderências intraperitoneais pós-cirúrgicas em cadelas, sobretudo nas relacionadas à serosa do cólon.

Palavras-chave: aderências, profilaxia, azul de metileno, avaliação laparoscópica, trauma cirúrgico, cadelas.

\section{INTRODUCTION}

Intraperitoneal adhesions are fibrous bands of connective tissue with blood vessels and neurons in some cases. Adhesions usually are formed after surgical trauma, inflammation, ischemia and/or infection of the peritoneum, leading to abnormal connections among serosa surfaces due to imbalance

IFaculdade de Agronomia e Medicina Veterinária (FAMV), Universidade de Passo Fundo (UPF), Passo Fundo, RS, Brasil.

IIDepartamento de Medicina Veterinária, Escola de Veterinária e Zootecnia (EVZ), Universidade Federal de Goiás (UFG), Goiânia, GO, Brasil.

IIIMédica Veterinária autônoma, Marabá, PA, Brasil.

${ }^{\text {IV }}$ Centro de Controle de Zoonoses, Prefeitura Municipal de Anápolis, Anápolis, GO, Brasil.

vepartamento de Medicina Veterinária, Campus CEDETEG, Universidade Estadual do Centro-Oeste (UNICENTRO), Guarapuava, PR, Brasil.

${ }^{\mathrm{VI}}$ Departamento de Clínica de Pequenos Animais, Centro de Ciências Rurais (CCR), Universidade Federal de Santa Maria (UFSM), Av. Roraima, 97105-900, n 1000, Cidade Universitária, Camobi, Santa Maria, RS, Brasil. E-mail: mauriciovelosobrun@hotmail.com. Autor para correspondência. 
between fibrin deposition and fibrinolysis (VAN DER WAL \& JEEKEL, 2007).

The cytokines IL-1, IL-6 and TNF- $\alpha$, prostaglandins, nitric oxide and the reactive oxygen specimens (ROS) are the main inflammatory mediators involved on the reduction of the fibrinolysis (HELLEBRECKERS \& KOOISTRA, 2011). The combined action of such mediators leads to the depletion of tissue plasminogen activator (t-PA) activity due to increased activity of the plasminogen activation inhibitors (PAI-1 and PAI2 ) in the peritoneal fluid and injured organ surfaces. The impaired fibrinolysis allows the colonization of the fibrin adhesions by fibroblasts, which produce extracellular matrix and create permanent and organized fibrous adhesions (VAN DER WAL \& JEEKEL, 2007; ARUNG et al., 2011).

In human patients, millions of dollars are spent on the treatment of intraperitoneal adhesionsrelated syndromes, such as bowel obstructions, infertility and chronic pelvic pain (ARUNG et al., 2011; HELLEBRECKERS \& KOOISTRA, 2011). The study of adhesions in the veterinary context is sparse and its real incidence was not well established. Adhesions can be found in dogs following abdominal trauma, laparotomy, laparoscopic or video-assisted surgery as a simple surgical finding or causing severe colonic obstruction and other life-threatening syndromes (HANDERSON, 1996; COOLMAN et al., 1999; BRUN et al., 2004).

Methylene blue (MB) is a partial liposoluble organic dye that presents low toxicity and effectiveness in controlling oxidative stress (RAŞA et al., 2002), which is widely employed in human patients for tubal patency, intestinal and urinary suture line leakage tests and for lymph node localization in oncologic patients (CETIN et al., 2003). Intraperitoneal MB solution attenuates postsurgical oxidative stress and decreases intraperitoneal adhesion formation enhancing peritoneal fibrinolysis (BINDA et al., 2003; MAHDY et al, 2008). Such effect is attributed to the decline of oxidative stress following neutralization of the instable electron from molecules of xanthine oxidase and NADPH-oxidase (HEYDRICK et al., 2007). Although several studies suggest the benefits of MB solution on the prevention of postsurgical adhesion formation, such hypothesis has not been tested in dog models for veterinary routine purpose.

In such context, the present study aimed to evaluate the effectiveness of methylene blue $1 \%$ solution intraperitoneally on the reduction of postsurgical adhesion formation in a canine surgical trauma and foreign body model.

\section{MATERIAL AND METHODS}

Twenty bitches ranging from 8 to $13 \mathrm{~kg}$ were evaluated. The $1 \%$ methylene blue sterile solution was prepared aseptically in laminar flow hood, following dissolution of sterile methylene blue powder in distilled water. The aseptic preparation of the MB solution was validated following aerobic and anaerobic microbiological tests.

The dogs were fasted for 12 hours. The abdominal area was clipped prior to surgery. Neuroleptoanalgesia was performed with intramuscular injection of a mixture of tramadol $\left(2 \mathrm{mg} \mathrm{kg}^{-1}\right)$ and chlorpromazine chloride $\left(1 \mathrm{mg} \mathrm{kg}^{-1}\right)$. Anesthetic induction was accomplished with an intravenous bolus of propofol $\left(5 \mathrm{mg} \mathrm{kg}^{-1}\right.$, to effect), twenty minutes after premedication. The anesthetic maintenance was performed after endotracheal intubation with halothane vaporized in $100 \%$ oxygen, delivered in $20 \mathrm{ml} \mathrm{kg}^{-1}$ of body weight in semi-closed circuit.

Adhesions were induced using a foreign body and partial colonic deserosation model (OZEL et al., 2005). An 8-cm celiotomy was carried out, followed by excision of the falciform ligament and total omentectomy. Ovariohysterectomy was carried out using the triple-clamping technique. The ovarian pedicles and uterine body were ligated using a single Miller's knot ligature. A blue polyfilament polyester non-absorbable thread, USP 1, was used for prophylactic hemostasis and as a foreign body to induce adhesions. Afterwards, partial deserosation was carried out in an 8-cm segment of the descending colon with scalpel blade and sterile gauze.

Following colonic deserosation, the animals were randomly assigned into one of two groups, before abdominal closure. Bitches belonging to the MB group were given $1 \mathrm{mg} \mathrm{kg}^{-1}$ of $1 \%$ methylene blue sterile solution intraperitoneally. The MB solution was prepared about 12 hours before surgery, in a flow hood under aseptic conditions, using sterile MB powder and distilled water, and stored in sterile assay tubes. The MB solution was recovered from the assay tube and instilled into the abdominal cavity using a syringe with needle, under aseptic condition. The dogs from the CT group received no intraperitoneal infusion. The abdominal wall was closed using an interrupted cross mattress pattern, with 2-0 polyglycolic acid thread. Skin closure was performed in a routine fashion.

Postoperative care included the administration of amoxicillin (15 $\mathrm{mg} \mathrm{kg}^{-1} \mathrm{IM}$ SID, for 5 days), tramadol chloride $\left(2 \mathrm{mg} \mathrm{kg}^{-1} \mathrm{SC}\right.$ TID, 
for 3 days) and wound cleaning with $0,9 \%$ sodium chloride twice a day, for 10 days, when skin sutures were removed. All animals were clinically assisted daily, for 30 days postoperatively. The presence of clinical signs resembling adhesion-related syndrome was assessed during the clinical assessments.

Laparoscopic investigation was performed on the $15^{\text {th }}$ day post-op for the assessment of adhesion formation. After patient preparation and general anesthesia, a mini-celiotomy was carried out $2 \mathrm{~cm}$ cranially to the surgical scar and an 11-mm trocar was introduced into the abdominal cavity using the open technique. Afterwards, a $10-\mathrm{mmHg} \mathrm{CO}_{2}$ pneumoperitoneum was created. A $10-\mathrm{mm} 30^{\circ}$ rigid endoscope was introduced into the abdomen for initial evaluation. A 6-mm trocar was placed at the left hypochondrium for insertion of an atraumatic forceps. The ovarian pedicles were assessed after mild lateral rotation of the thorax, as mentioned in other trial (SILVA et al., 2011). Afterwards, the dogs were positioned in dorsal recumbency for viewing the pelvic organs and the distal colon.

A composed scoring system (MORENO et al., 1996) was especially adapted for laparoscopic classification of adhesions in the canine model (Table 1). Blind determination of the adhesion scores was attributed by the same surgeon in all animals. Adhesiolysis would be performed whenever it was possible during laparoscopic assessment.

The data were submitted to the Kolmogorov-Smirnov's normality test. Body weight and overall surgical time were compared between groups using one-way ANOVA. The adhesion scores were compared between groups using the nonparametric Mann-Whitney's test. Additionally, the Fisher's exact test was employed to compare the frequency of adhesions on the potential adhesiogenic lesions in the animals belonging to the MB or CT groups. For all statistical analysis the GRAPHPAD PRIMSP 4 software was used. Difference would be considered significant if $\mathrm{P}<0.05$.

\section{RESULTS AND DISCUSSION}

There was no difference between groups considering body weight and surgical time. Mean body weight and surgical time was $10.2 \pm 2.1 \mathrm{~kg}$ and $35.4 \pm 5.5$ minutes for the $\mathrm{MB}$ group, and $9.8 \pm 3.0 \mathrm{~kg}$ and $33.8 \pm 3.4$ for the CT group, respectively. The mean time of the laparoscopic staging procedure, from skin incision to wound closure, was 11.6 \pm 4.3 minutes for the MG group and 10.8 \pm 5.7 minutes for the CT group.

\begin{tabular}{|c|c|}
\hline \multicolumn{2}{|c|}{$\begin{array}{l}\text { Composing scoring system* for laparoscopic } \\
\text { classification of postoperative adhesions in bitches } \\
\text { following surgical trauma and } 1 \mathrm{mg} \mathrm{kg}^{-1} \text { of } 1 \% \\
\text { methylene blue solution intraperitoneally (MB } \\
\text { group) or no treatment (CT group). }\end{array}$} \\
\hline Criterion & Score \\
\hline Number of adhesions & 1 for each \\
\hline \multicolumn{2}{|l|}{ Adhesion site } \\
\hline Pelvic fat and abdominal wall & 1 \\
\hline $\begin{array}{l}\text { Pelvic fat and colon, uterine stump or bladder; } \\
\text { uterine stump and colon; mesentery and } \\
\text { ovarian pedicle }\end{array}$ & 2 \\
\hline $\begin{array}{l}\text { Uterine stump and intestinal loop; ovarian } \\
\text { pedicle and intestinal loop or right lobe of the } \\
\text { pancreas }\end{array}$ & 3 \\
\hline $\begin{array}{l}\text { Colon or intestinal loop and abdominal wall; } \\
\text { uterine stump and bladder }\end{array}$ & 4 \\
\hline $\begin{array}{l}\text { Uterine stump, bladder, intestinal loop and } \\
\text { colon }\end{array}$ & 5 \\
\hline \multicolumn{2}{|l|}{ Vascularization } \\
\hline No & 0 \\
\hline Yes & 1 \\
\hline \multicolumn{2}{|l|}{ Extension } \\
\hline Single band/fiber & 1 \\
\hline Multiple bands/fibers & 3 \\
\hline \multicolumn{2}{|l|}{ Strength } \\
\hline Type I (thin/simple, with minimal dissection) & 1 \\
\hline $\begin{array}{l}\text { Type II (dense/dissection needed to separate } \\
\text { adherent area) }\end{array}$ & 2 \\
\hline $\begin{array}{l}\text { Type III (fibrous/dissection needed to cut } \\
\text { adhesions) }\end{array}$ & 3 \\
\hline $\begin{array}{l}\text { Type IV (granuloma/difficult or impossible to } \\
\text { dissect) }\end{array}$ & 4 \\
\hline
\end{tabular}

*Adapted from MORENO et al. (1996).

All patients presented intra-abdominal adhesions during laparoscopic assessment, regardless of the group. Intraperitoneal adhesions can affect $100 \%$ of the patients submitted to surgical trauma (VAN DER WAL \& JEEKEL, 2007), as described in the current study. Adhesions can lead to technical difficulties during a new surgical abdominal exploration, which may increase both operative time and risk of intestinal iatrogenic lesions, even for experienced surgeons (ARUNG et al., 2011; HELLEBRECKERS \& KOOISTRA, 2011).

Despite the high occurrence of intraperitoneal adhesions, no clinical signs resembling secondary disease associated to adhesion formation were noted on the animals during 30 days of assessment. Such fact was reported in other study involving postoperative laparoscopic assessment of colonpexy in dogs (BRUN et al., 2004). However, severe colonic obstruction and other long-term life- 
threatening syndromes may occur in dogs bearing postoperative adhesion (HANDERSON, 1996; COOLMAN et al., 1999). Therefore, the prophylaxis of adhesion formation in canine patients should not be neglected.

MB solution presents low cost, easy acquisition, high security of use, quick metabolism, low toxicity and effectiveness in preventing adhesion formation, as described in other animal models (KLUGER et al., 2000; RAŞA et al., 2002; HEYDRICK et al., 2007). However, its efficiency had not been tested intraperitoneally as a single prophylactic option in dogs and human patients to our knowledge. Such fact motivated the accomplishment of the current study. The choice of $1 \%$ dilution was based on the results of successful dose-dependent randomized trials in the rat uterine serosa damage model (KLUGER et al., 2000; MAHDY et al., 2007). The dose of $1 \mathrm{mg} \mathrm{kg}^{-1}$ evaluated in the present study was based on the results of other assessments involving reduction of adhesiogenesis in rats (RAŞA et al., 2002).

MB group presented lower adhesion scores $(\mathrm{P}=0.043)$ than the CT group (Table 2$)$. Such result was probably reached due to its efficient short-action anti-oxidant mechanism, as confirmed in several studies (CETIN et al., 2003; DINC et al., 2006; HEYDRICK et al., 2007). Oxidative stress is

Table 2 - Adhesion scores and sites in bitches following surgical trauma and intraperitoneal infusion of $1 \mathrm{mg} \mathrm{kg}^{-1}$ of methylene blue $1 \%$ solution (MB group) or no infusion (CT group). Idem 1, adicionalmente a tabela deve ter no máximo três linhas continuas horizontais. As demais devem ser deletadas ou substituídas por linhas tracejadas

\begin{tabular}{|c|c|c|c|c|c|c|c|c|}
\hline \multirow{2}{*}{ Group } & \multirow{2}{*}{ animals } & \multirow{2}{*}{ Adhesion score } & \multirow{2}{*}{ Mean } & \multirow{2}{*}{ Median } & \multirow{2}{*}{ SD } & \multicolumn{3}{|c|}{ Adhesion sites --- } \\
\hline & & & & & & OP & $\mathrm{CO}$ & US \\
\hline \multirow{10}{*}{ MB } & 1 & 22 & \multirow{10}{*}{13.9} & \multirow{10}{*}{12} & \multirow{10}{*}{5.6} & $\mathrm{X}$ & $\mathrm{X}$ & - \\
\hline & 2 & 8 & & & & - & - & X \\
\hline & 3 & 21 & & & & $X$ & $X$ & - \\
\hline & 4 & 7 & & & & $\mathrm{X}$ & - & - \\
\hline & 5 & 20 & & & & $\mathrm{X}$ & - & $\mathrm{X}$ \\
\hline & 6 & 10 & & & & - & - & $\mathrm{X}$ \\
\hline & 7 & 12 & & & & $\mathrm{X}$ & - & $\mathrm{X}$ \\
\hline & 8 & 17 & & & & $\mathrm{X}$ & - & $\mathrm{X}$ \\
\hline & 9 & 12 & & & & - & - & $\mathrm{X}$ \\
\hline & 10 & 10 & & & & - & - & $\mathrm{X}$ \\
\hline \multirow{10}{*}{ CT } & 11 & 27 & \multirow{10}{*}{20.5} & \multirow{10}{*}{18.5} & \multirow{10}{*}{6.4} & $\mathrm{X}$ & $\mathrm{X}$ & $\mathrm{X}$ \\
\hline & 12 & 15 & & & & $\mathrm{X}$ & - & $\mathrm{X}$ \\
\hline & 13 & 18 & & & & - & $X$ & $X$ \\
\hline & 14 & 21 & & & & $X$ & $X$ & $X$ \\
\hline & 15 & 35 & & & & $X$ & $X$ & $X$ \\
\hline & 16 & 16 & & & & - & $X$ & $X$ \\
\hline & 17 & 16 & & & & - & $X$ & $X$ \\
\hline & 18 & 23 & & & & $X$ & $X$ & - \\
\hline & 19 & 15 & & & & $X$ & - & - \\
\hline & 20 & 19 & & & & $X$ & $X$ & - \\
\hline
\end{tabular}

Mann-Whitney test; $\mathrm{P}=0.043$. SD: standard deviation; OP: ovarian pedicle; $\mathrm{CO}$ : colon; US: uterine stump; " $\mathrm{X}$ " indicates presence of adhesions affecting the ovarian pedicle, colon and/or uterine stump.

Ciência Rural, v.43, n.9, set, 2013. 
highly increased up to 24 hours in the peritoneum after surgery (BINDA et al., 2003; ARUNG et al., 2011). Methylene blue doesn't affect the deposition of fibrin bands on the surgical site, but controls the oxidative stress enhancing peritoneal fibrinolysis (HEYDRICK et al., 2007). The early control of the oxidative stress allows for the reduction of inflammatory response, increase of the tissue-type plasminogen activator (t-PA) activity and decrease of the plasminogen activation inhibitors (PAI-1, PAI-2) activity (BINDA et al., 2003). In fact, these combined actions affect the balance between fibrin deposition and fibrinolysis, enhancing the fibrinolysis cascade (HELLEBRECKERS \& KOOISTRA, 2011).

Besides decreasing the overall adhesion score, intraperitoneal $\mathrm{MB}$ solution leaded to lower occurrence of adhesions to the colon $(\mathrm{P}=0.023)$. Colonic adhesions were diagnosed in two $(20 \%)$ out of ten bitches that received $1 \mathrm{mg} \mathrm{kg}^{-1}$ of $1 \% \mathrm{MB}$ solution intraperitoneally, while eight $(80 \%)$ out of ten animals from CT group which presented colonic adhesions (Figure 1-D). Deserosation, desiccation and ischemia/reperfusion injuries usually lead to acute and short-term formation of ROS (BINDA et al., 2003), which can be controlled by methylene blue (RAŞA et al., 2002; HEYDRICK et al., 2007; YILDIZ et al., 2011). Thus, the reduced rate of colonic adhesions was probably reached due to the antioxidant mechanism of MB solution over the colonic serosa and consequent enhanced fibrinolysis. Such hypothesis was confirmed in other trials involving the uterine horn deserosation (KLUGER et al., 2000; YILDIZ et al., 2011) or cauterization (CETIN et al., 2003), cecal serosa damage (RAŞA et al., 2002; MAHDY et al., 2008), section and anastomosis of the right colon (DINC et al., 2006) and parietal peritoneum ischemia (HEYDRICK et al., 2007) in blinded controlled trials rats.

Although efficient in reducing adhesions due to serosa damage, MB failed to avoid adhesion due to foreign body. Ligation of the ovarian pedicles with polyester thread caused adhesion between the pedicle and right pancreatic lobe (Figure 1A), intestinal loop (Figure 1-C) or mesentery in six dogs $(60 \%)$ from the MB group and in $7(70 \%)$ from the $\mathrm{CT}$ group $(\mathrm{P}>0.05)$. Both $\mathrm{MB}$ and $\mathrm{CT}$ groups presented 7 cases $(70 \%)$ of adhesions involving the uterine stump and the bladder (Figure 1B), bowel or pelvic fat $(\mathrm{P}>0.05)$. It is known that intraperitoneal $\mathrm{MB}$ is absorbed and metabolized within the first

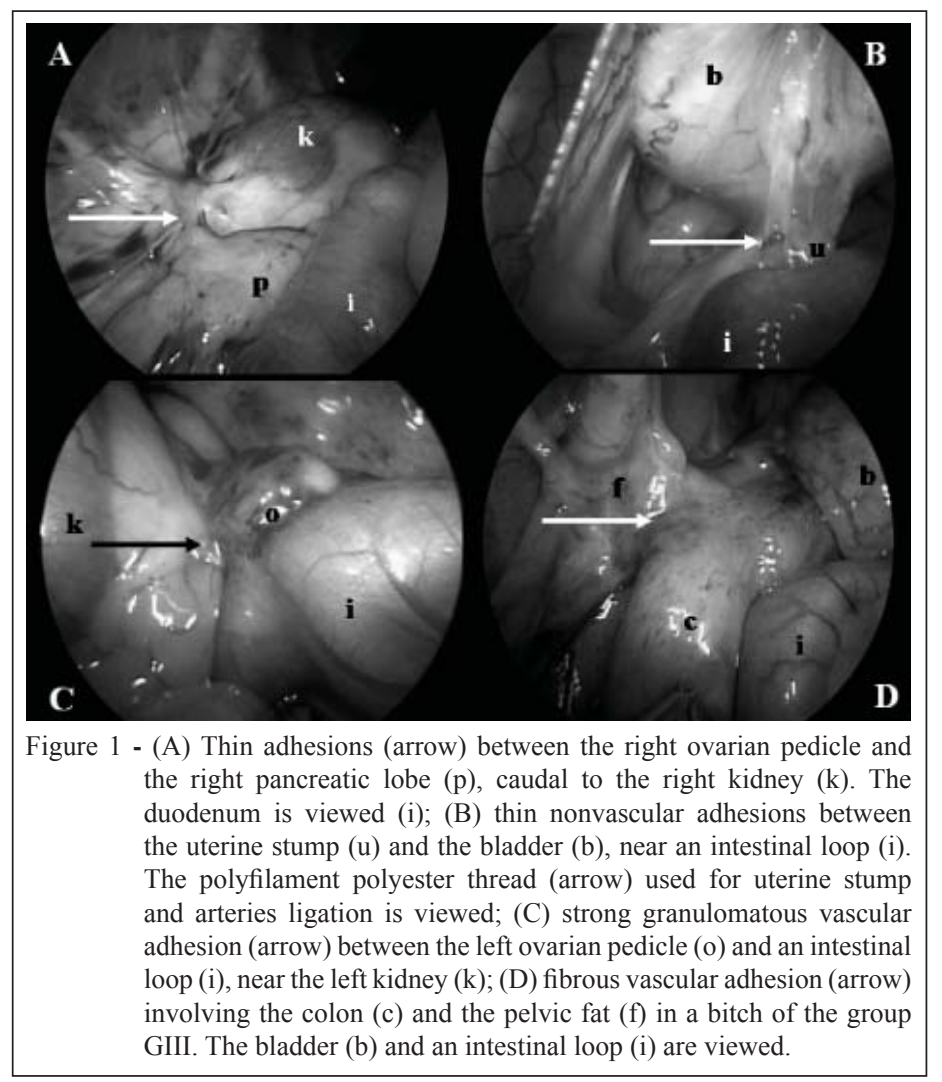

Ciência Rural, v.43, n.9, set, 2013. 
24 hours (KLUGER et al., 2000) and that foreign bodies such as threads and meshes may induce chronic inflammation and long-term tissue reaction (ARUNG et al., 2011). Thus, barrier methods such as hyaluronate/carboxymethilcellulose (HA/CMC) and polytetrafluoroethylene (PTFE) biocompatible membranes seems the most rational choice (ARUNG et al., 2011), rather than methylene blue. In a metaanalysis, it was found that low molecular weight intraperitoneal solutions present low effectiveness in comparison to barrier methods, especially in the presence of foreign body (OZEL et al., 2005).

The high occurrence of surgical thread-inflicted adhesions highlights that nonabsorbable polyfilament thread should be avoided for ovariohysterectomies, once complications related to foreign body type reactions and adhesion formation are major concerns (HANDERSON, 1996; COOLMAN et al., 1999).

There were no cases of adhesions at the abdominal closure site in the current study. In contrast, adhesions involving the omentum and the abdominal wall were described in dogs submitted to laparoscopy (BRUN et al., 2004). Omentectomy was performed in the current study in order to prevent the formation of adhesions between the omentum and the abdominal wall, ligatures and/or colonic deserosation site, which could impair the assessment of the effectiveness of methylene blue solution on the prophylaxis of adhesion formation in this dog model. In fact, adhesions between the omentum and the abdominal wall may be beneficial, as it prevents undesirable adhesions involving other viscera and the parietal peritoneal suture line (HENDERSON, 1996). Those kinds of adhesions inflict severe risk of accidental organ perforation in case of a second laparotomy (ARUNG et al., 2011). Although visceral adhesions to the abdominal suture line were not described in the current study, it is highlighted that such potential complication should not be neglected.

Finally, the current study revealed that methylene blue also plays an important role on the prophylaxis of postoperative adhesions in the canine specie. Nonetheless, other studies revealed that MB solution not only influences adhesion formation, but also delays the healing of intestinal anastomosis (DINC et al., 2006) and abdominal wall (KALAYCI et al., 2011). Thus, MB should be further evaluated before its routine use, especially due to such dual effect. Moreover, methylene blue should be used in patients submitted to abdominal surgical trauma, especially those causing desiccation and deserosation or ischemia/reperfusion, not foreign body type injuries, in order to prevent adhesion formation.

\section{CONCLUSION}

In conclusion, $1 \%$ methylene blue solution attenuated the adhesion formation after abdominal surgical trauma in dogs. Methylene blue was effective on preventing adhesion formation due to damage to visceral serosa, but not those caused by non-absorbable foreign body.

\section{ACKNOWLEDGEMENTS}

The authors would like to thank Fundação Educacional de Penápolis/Universidade Federal de Goiás (FUNEPE/UFG) for financial support to this study, and Dr. Juan Carlos Duque Moreno for translation support.

\section{ETHICS COMMITTEE AND BIOSAFETY}

The current study was carried out following approval by the Committee for Animal Welfare in Research (UFG, registration number 044/2007).

\section{REFERENCES}

ARUNG, W. et al. Pathophysiology and prevention of postoperative peritoneal adhesions. World Journal of Gastroenterology, v.17, n.41, p.4545-4553, 2011. Available from: <http://www.ncbi. nlm.nih.gov/pmc/articles/PMC3225091/pdf/WJG-17-4545.pdf $>$. Accessed: Jan. 20, 2012. doi: 10.3748/wjg.v17.i41.4545.

BINDA, M.M. et al. Reactive oxygen species and adhesion formation - clinical implications in adhesion prevention. Human Reproduction, v.18, n.12, p.2503-2507, 2003. Available from: $<$ http://humrep.oxfordjournals.org/content/18/12/2503.full. pdf + html $>$. Accessed: Set. 11, 2010. doi: 10.1093/humrep/ $\operatorname{deg} 481$.

BRUN, M.V. et al. Evaluation of two different sutures for incisional laparoscopic colonpexy in dogs. A experimental study. Brazilian Journal of Veterinary Research and Animal Science, v.41, p.154-161, 2004. Available from: <http://www.revistasusp. sibi.usp.br/pdf/bjvras/v41n3/25213.pdf>. Accessed: Set. 11, 2010.

CETIN, M. et al. Use of methylene blue and N,Ocarboxymethylchitosan to prevent postoperative adhesions in a rat uterine horn model. Fertility and Sterility, v.80, n.2, p.698-701, 2003. Available from: <http://www.sciencedirect.com/science/ article/pii/S0015028203007775>. Accessed: Set. 11, 2010. doi: 10.1016/S0015-0282(03)00777-5

COOLMAN, B.R. et al. Partial colonic obstruction following ovariohysterectomy: a report of three cases. Journal of the American Animal Hospital Association, v.35, n.2, p.169-172, 1999. Available from: <www.jaaha.org/content/35/2/169.full. pdf>. Accessed: Set. 11, 2010.

DINC, S. et al. Methylene blue prevents surgery-induced peritoneal adhesions but impairs the early phase of anastomotic wound healing. Canadian Journal of Surgery, v.49, n.5, p.321328, 2006. Available from: <http://www.ncbi.nlm.nih.gov/pmc/ articles/PMC3207574/pdf/20061000s00007p321.pdf >. Accessed: Nov. 20, 2010. 
HELLEBRECKERS, B.W.J.; KOOISTRA, T. Pathogenesis of postoperative adhesion formation. British Journal of Surgery, v.98, 1503-1516, 2011. Available from: <http://onlinelibrary. wiley.com/doi/10.1002/bjs.7657/pdf $>$. Accessed: Dec. 15, 2011. doi: 10.1002/bjs.7657.

HENDERSON, R.A. Formação de aderências. In: BOJRAB, M.J. (Ed.). Mecanismos da moléstia na cirurgia dos pequenos animais. 2.ed. São Paulo: Manole, 1996. p.133-138.

HEYDRICK, S.J. et al. Intraperitoneal administration of methylene blue attenuates oxidative stress, increases peritoneal fibrinolysis, and inhibits intraabdominal adhesion formation. Journal of Surgical Research, v.143, p.311-319, 2007. Available from: <http://www.sciencedirect.com/science/article/ pii/S0022480406005981>. Accessed: Jan. 24, 2011. doi: 10.1016/j.jss.2006.11.012.

KALAYCI, M.U. et al. The effects of methylene blue on adhesion formation in a rat model of experimental peritonitis. Turkish Journal of Trauma and Emergency Surgery, v.17, n.3, p.205209, 2011. Available from: <http://www.journalagent.com/z4/ download_fulltext.asp?pdir=travma\&plng=\&un=UTD-93609>. Accessed: Mar. 10, 2012. doi: 10.5505/tjtes.2011.93609.

MAHDY, T. et al. Effect of methylene blue on intra-abdominal adhesion formation in rats. International Journal of Surgery, v.6, n.6, p.452-455, 2008. Available from: <http://www.sciencedirect. com/science/article/pii/S1743919108001131>. Accessed: Mar. 10, 2012. doi: 10.1016/j.ijsu.2008.08.004.

MORENO, A. et al. Influence of abdominal incision on the formation of postoperative peritoneal adhesions: an experimental study in rats. European Journal of Surgery, v.162, p.181-
185, 1996. Available from: <http://www.ncbi.nlm.nih.gov/ pubmed/8695731>. Accessed: Mar. 20, 2010.

OZEL, H. et al. Induction and assessment methods used in experimental adhesion studies. Wound Repair and Regeneration, v.13, p.358-364, 2005. Available from: < http://onlinelibrary.wiley. com/doi/10.1111/j.1067-1927.2005.130402.x/pdf>. Accessed: Mar. 15, 2011. doi: 10.1111/j.1067-1927.2005.130402.x.

RAŞA, K. The effect of methylene blue on peritoneal adhesion formation. Turkish Journal of Gastroenterology, v.13, n.2, p.108-111, 2002. Available from: <http://www.turkgastro.org/ pdf/434.pdf>. Accessed: Mar. 10, 2010.

SILVA, M.A.M. et al. Single-port video-assisted ovariohysterectomy in bitches: retrospective study of 20 cases. Ciência Rural, v.41, n.2, p.294-300, 2011. Available from: $<$ http://www.scielo.br/pdf/cr/v41n2/a871cr4012.pdf $>$. Accessed: Nov. 12, 2011. doi: 10.1590/S0103-84782011005000013.

VAN DER WAL, J.B.C.; JEEKEL, J. Biology of the peritoneum in normal homeostasis and after surgical trauma. Colorectal Disease, v.9, suppl.2, p.9-13, 2007. Available from: <http://onlinelibrary. wiley.com/doi/10.1111/j.1463-1318.2007.01345.x/pdf>. Accessed: Mar. 10, 2010. doi: 10.1111/j.1463-1318.2007.01345.x.

YILDIZ, H. et al. The comparison of methylene blue and vitamin $\mathrm{E}$ in prevention of abdominal postoperative adhesion formation in rat uterine horn models. Biochemical and histopathologic evaluation. Acta Cirúrgica Brasileira, v.26, n.1, p.51-57, 2011. Available from: <http://www.scielo.br/pdf/acb/v26n1/ a10v26n1.pdf $>$. Accessed: Feb. 10, 2012. doi: 10.1590/S010286502011000100010 . 